been dated by the carbon-14 method, thus placing the beginning of the Alnus curve at $6620 \pm 125$ B.c.5. The pollen analysis from the upper part of the mire (Fig. $1, c$ ) indicates that its age is apparently not far from the time when the Alnus curve began. This correlates very well with the radiological dating from Sweden

Marine sediments resting directly upon a boreal terrestrial deposit have apparently not been previously reported in Norway. The occurrence of marine diatoms, as described above, indicates that sea-level was not far below the rock threshold and that waves were able to break over it, for example, during storms and exceptionally high-water levels. The minimum level of the boreal shore-line, judging by the evidence of the diatoms, was not far frem the present sea-level in the area. However, work on a graph of the movement of the shore-line is being carried out at present, and more detailed results will be published later.

Department of Limnology,

\section{Gunnar Gabrielsen}

University of Oslo,

Blindern, Norway.

March 9.

${ }^{2}$ Halden, Bertil E., Sverig. geol. Unders. Afh., Ser. C, No. 310 (1922). Sandegren, R., Sverig. geol. Unders. Afh., Ser. Aa, No. 173 (1931). 'Alin, J., Geol. Fören. Stockh. Förh., 66 (3), 355 (1944).

- Sandegren, R., Bohuslans geologi, Svenska Gods och Gardar, Uddevalla (1943).

'Lundqvist, G., Sverig. geol. Unders. Afh., Ser. C., No. 557 (1957)

\section{Olivine-Spinel Transformation}

Is the light of A. E. Ringwood's recent synthesis of a spinel form of fayalite (private communication), $\mathrm{Fe}_{2} \mathrm{SiO}_{4}$ (the iron end-member of the fayalite-forsterite mixtures which comprise the bulk of natural olivines), it seemed worth while to attempt a synthesis of a spinel form of forsterite, $\mathrm{Mg}_{2} \mathrm{SiO}_{4}$. Ringwood prepared the fayalite-spinel at about 50 kilobars and $500^{\circ} \mathrm{C}$., and his calculations indicated that the forsterite-spinel should become stable at about 100 kilobars and $500^{\circ} \mathrm{C}$. It is possible that olivine is abundant in deeper layers of the Earth $(50-1,000 \mathrm{~km}$.) and hence some knowledge of its phase transitions would be of geological interest ${ }^{1}$.

To study these possible phase transitions, appropriate mixtures of dry and hydrous oxides were loaded into a carbon capsule contained in a highpressure, high-temperature apparatus. After the pressure on the capsule was increased to the desired level, it was electrically heated to about $550^{\circ} \mathrm{C}$. for

Table 1

\begin{tabular}{|c|c|c|}
\hline Charge & $\begin{array}{c}\text { Pressure } \\
\text { (kilobars) }\end{array}$ & Products identified \\
\hline $\begin{array}{l}2 \mathrm{Mg}(\mathrm{OH})_{2}+\mathrm{SiO}_{2} \cdot n \mathrm{H}_{2} \mathrm{O} \\
\mathrm{Fe}+\mathrm{Fe}_{3} \mathrm{O}_{4}+\mathrm{SiO}_{2} \cdot n \mathrm{H}_{2} \mathrm{O}\end{array}$ & $\begin{array}{c}95-130 \\
110\end{array}$ & $\begin{array}{l}\text { Forsterite } \\
\text { Ringwood's fayalite- } \\
\text { spinel (Debye-Scherrer } \\
\text { patterns agree) }\end{array}$ \\
\hline $\begin{array}{l}\mathrm{Fe}+\mathrm{Fe}_{3} \mathrm{O}_{4}+\mathrm{MgO}+ \\
\mathrm{SiO}_{2} \cdot n \mathrm{H}_{2} \mathrm{O}\end{array}$ & 110 & $\begin{array}{l}\text { Forsterite, fayalite- } \\
\text { spinel }\end{array}$ \\
\hline Hawailan olivine & 93-(hot) & $\begin{array}{l}\text { Olivine melted and } \\
\text { frozen this run. Olivine } \\
\text { recovered }\end{array}$ \\
\hline $\begin{array}{l}\text { Moist Hawaiian olivine } \\
2 \mathrm{Mg}(\mathrm{OH})_{2}+0.9 \mathrm{SiO}_{2}+\end{array}$ & $90-110$ & Olivine unchanged \\
\hline $\begin{array}{c}0.1 \mathrm{GeO}{ }_{2}+\mathrm{H}_{2} \mathrm{O} \\
2 \mathrm{Mg}(\mathrm{OH})_{3}+\mathrm{SiO}_{3} \cdot n \mathrm{H}_{2} \mathrm{O}\end{array}$ & 110 & Forsterite \\
\hline $2+\mathrm{NiO} \cdot \mathrm{SiO}_{2} \cdot n \mathrm{Ni}_{2} \mathrm{O}$ & $\begin{array}{c}110 \\
90-110\end{array}$ & $\begin{array}{l}\text { Forsterite } \\
\text { Nickel forsterite (no }\end{array}$ \\
\hline $2 \mathrm{ZnO} \cdot \mathrm{SiO}_{2} \cdot n \mathrm{H}_{2} \mathrm{O}$ & 90 & $\begin{array}{l}\text { New phase, r.i. } 1 \cdot 78 \text {, } \\
\text { biaxial. No spinel }\end{array}$ \\
\hline
\end{tabular}

about $20 \mathrm{~min}$. (Crystals of 10 or $20 \mu$ average diameter formed in $5 \mathrm{~min}$.) Then the sample was quenched to room temperature and the pressure was reduced to atmospheric. In this way any phases formed at high pressure would tend to be preserved. Various hydrated phases formed if the maximum temperature did not exceed about $500^{\circ} \mathrm{C}$.

Table I summarizes the results of these experiments.

Thus no other olivinic spinel other than Ringwood's fayalite-spinel formed in these experiments. Perhaps higher pressures are necessary. This work will be continued.

I am indebted to A. E. Ringwood and Prof. F. Birch for stimulating the work on this problem and for providing some of the oxide mixtures.

R. H. WENTORF, JUN.

General Electric Co. Research Laboratory,

$$
\begin{aligned}
& \text { P.O. Box 1088, } \\
& \text { Schenectady, } \\
& \text { New York. }
\end{aligned}
$$

March 20.

${ }^{1}$ Nature, 178, 1303 (1956).

\section{PAL/EOMAGNETISM}

\section{Late Tertiary Geomagnetic Field in North- western Canada}

The fundamental assumption made in interpreting palæomagnetic results is that the average geomagnetic field corresponds to that of a central axial dipole. This communication reports on some palæomagnetie results which support this assumption and which were made on Late Tertiary volcanic rocks, which were collected during the summer of 1955 from north-western Canada by field geologists of the Geological Survey of Canada from flat-lying, undisturbed, vesicular basalts.

Forty-eight samples were collected from four different localities. The largest suite, twenty-nine amples, was collected by J. O. Wheeler from lavas exposed near Whitehorse, Yukon, at a latitude of $60.5^{\circ} \mathrm{N}$. and longitude of $135.0^{\circ} \mathrm{W}$. Another nine samples were collected by W. H. Poole near Wolf Lake, Yukon, at $60 \cdot 0^{\circ} \mathrm{N}$. and $130.5^{\circ} \mathrm{W}$. L. H. Green collected six samples near Selkirk, Yukon, at $63 \cdot 0^{\circ} \mathrm{N}$. and $138 \cdot 0^{\circ} \mathrm{W}$., and J. D. Aitken collected four samples near Surprise Lake, British Columbia, at $59 \cdot 5^{\circ} \mathrm{N}$. and $134.0^{\circ} \mathrm{W}$.

These samples were measured on a magnetometer of the rock generator type at the Geological Survey of Canada during 1958. The results of these measurements are shown in Fig. 1 on a stereographic projection, full and open eircles representing north poles on the lower and upper hemispheres respectively. All the rocks collected by Wheeler and Green are reversely magnetized while the rest are normal except for two of Poole's samples, which are almost horizontally polarized.

The mean direction of these rock samples has been computed by reversing all the reversely polarized rocks and adding them to the normal ones. The two horizontally polarized samples are considered to be anomalous, due perhaps to magnetization caused by lightning, and have not been included in the statistical analysis. The mean direction, $H$, with its Fisher statisties, has been listed in Table 1, where it is compared with the field, $F$, produced by a central axial dipole and the present geomagnetic field, $F^{\prime}$, at 